
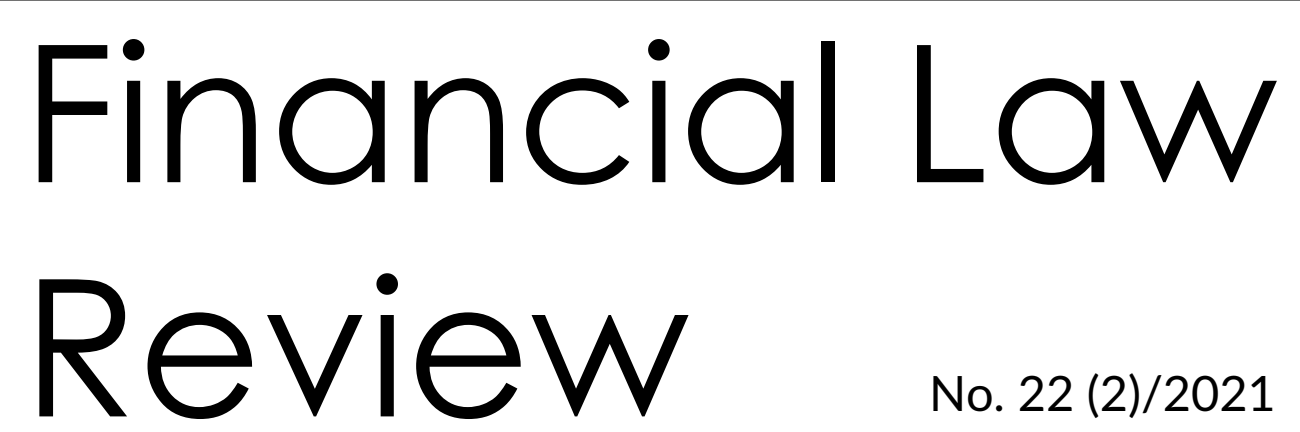

No. $22(2) / 2021$

UNIVERSITY OF GDAŃSK • MASARYK UNIVERSITY • PAVEL JOZEF ŠAFÁRIK UNIVERSITY • UNIVERSITY OF VORONEZH

http://www.ejournals.eu/FLR

ŁUKASZ KIELIN*

\title{
CONSTITUTIONALISATION OF FISCAL RULES IN TIMES OF FINANCIAL CRISES - A CURE OR A TRAP?
}

\begin{abstract}
The global financial crisis of 2008 undoubtedly had a significant impact on the constitutional regulation of economic and financial matters. As a consequence of economic downturn six EU Member States (Germany, Spain, Slovakia, Slovenia, Italy and Hungary) have amended their constitutions. With economic crisis caused by global pandemic of, the new discussion about constitutional fiscal policy rules is expected. New economic downturn is one of the most important challenges for the constitutional fiscal rules, which undoubtedly will verify their functioning and effectiveness.

The main purpose of this paper is to find out if constitutional fiscal policy rules is a cure or trap in times of financial crisis. According to the hypothesis adopted, constitutional fiscal rules can be an effective tool. The article has the following structure. In the first and second part I describe constitutional fiscal rules. The third part concerns the method of constitutionalisation. Subsequently, I am focus on effectiveness of constitutional fiscal policy rules. The last part of the article contains conclusions.
\end{abstract}

Key words: budget, public finances, Constitution, fiscal policy rules, debt rule.

JEL Classification: E62, H68

* PhD Candidate in Financial and Constitutional Law, Faculty of Law and Administration, University of Gdańsk, Poland. Contact email: kielin.lukasz1994@gmail.com. ORCID ID: 0000-0003-0046-9477. 


\section{Introduction}

Fiscal rules can be defined as a long-term constraint on fiscal policy, usually defined in terms of some indicator of aggregate fiscal behaviour. The rules at discretion cover the aggregate fiscal indicator, often expressed as a numerical ceiling or objective in proportion to GDP [Kopits, Symansky 1998: 2]. This kind of provision was introduced into Constitution of Poland of 1997. According to article 216 (5) of Constitution of Poland, it shall be neither permissible to contract loans nor provide guarantees and financial sureties which would engender a national public debt exceeding three-fifths of the value of the annual gross domestic product.

Constitutional fiscal restrictions are not new [Ginsburg 2019: 60-63; Gerapetritis 2019: 630], however the introduction of a maximum debt limit into constitutional level was some kind of novelty. Foregoing constitutional restrictions of fiscal policy were more general the provisions of article 216.5 of the Constitution of Poland, had no precedent in the constitutionalism of democratic states [Sokolewicz 2005: 17]. In the wake of the financial crisis of 2008, this opinion began to lose relevance.

During economic downturn, the majority of EU Member States adopted Treaty on Stability Coordination and Governance in the Economic and Monetary Union (hereinafter as: Fiscal Compact), which imposes limits on the size of structural deficit and public debt. The Fiscal Compact stipulates certain fiscal policy rules that Member States shall implement into their national legal order. In the lights of its provisions, the budgetary position of the general government of a Contracting Party shall be balanced or in surplus (Article 3(1)(a)), which means that the annual structural deficit of public budgets shall-generally-not exceed $0.5 \%$ of GDP, or $1 \%$ of GDP if the governmental debt is 'significantly below $60 \%$ of GDP and where risks in terms of long-term sustainability of public finances are low in terms of longterm sustainability of public finances are low (Article $3(1)(d))$. The fiscal rules set out in the Fiscal Compact shall take effect in the national law of the Contracting Parties through provisions of binding force and permanent character, preferably constitutional (Article $3(2))$. Although the Fiscal Compact is not part of the legal system of the EU, its adoption had a significant impact on the constitutional legal orders of EU Member States. The Fiscal Compact gave an significant impulse to introduce constitutional fiscal policy rules.

The global financial crisis of 2008 undoubtedly had a significant impact on the constitutional regulation of economic and financial matters. As a consequence of economic downturn six EU Member States (Germany, Spain, Slovakia, Slovenia, Italy and Hungary) have amended their constitutions. With economic crisis caused by global pandemic of, the 
new discussion about constitutional fiscal policy rules is expected. New economic downturn is one of the most important challenges for the constitutional fiscal rules, which undoubtedly will verify their operation and effectiveness. Because of the risk of exceeding the constitutional limit, some economists. Because of the risk of exceeding the constitutional limit, some economists decided to call for removing debt limit stipulated in article 216 (5) of Constitution of Poland or raising its limit to 90\% of GDP [Sawulski 2020]. These proposals, however seem doubtful.

\section{Financial Crisis and constitutional amendments}

It should be noted that the introduction of fiscal rules into constitutional level constitutes a self-limitation of society and a renunciation of significant political freedom [DębowskaRomanowska, 2010: 109]. It would seem that constitutional fiscal rules aims to ensure fiscal sustainability of state's economy, enhance transparency and efficiency of public spending and protect future generations against the risk of state bankruptcy.

The "anchoring" of fiscal rules on a constitutional basis serves to ensure fiscal sustainability. Constitutions are supreme law, they are characterized by a qualified revision process and resistance to short-term impulses - which makes constitutional fiscal policy rules less susceptible to current political needs. The constitutionalisation of fiscal rules is the way to "tie the hands" of politicians and contribute to maintaining budgetary discipline. The aim of introducing fiscal policy restrictions is to impose a permanent obligation on governments to conduct responsible economic policy of the state with particular emphasis on the state of public finances.

Moreover, the attention should be also paid to the coincidence between the constitutionalisation of fiscal restrictions and the condition of public finances. In many cases, establishing fiscal rules at the constitutional level is a response to the deteriorating fiscal situation [Ginsburg 2019: 63-64]. It should be also noted that the introduction of the constitutional debt limit in Poland took place in 1997, when the debt level remained below half of GDP. However, this does not mean, that the economic situation did not influence on legislator's decision - Polish debt rule was a response to financial crisis of the transformation period.

In the light of above, the constitutionalisation of fiscal policy restraints is a signal to financial markets indicating that corrective action to improve the economic situation was taken, which is particularly evident in the course of the 2008 financial crisis. 


\subsection{Germany}

Germany has an extraordinary tradition of constitutionalisation budgetary constraint. In the 1969 the so-called "golden rule" was introduced into Constitution of the Federal Republic of Germany (hereinafter as: Basic Law). However, in 2009, provisions were modified as a response to worsening fiscal situation. The constitutional reform was adopted before the ratification of the Fiscal Compact, which provisions were inspired by German solutions [Antos 2014: 212].

The current restrictions were introduced into Articles 109 and 115 of the Basic Law. The German legislator restricts the fiscal policy in two ways - firstly by a general reference to the provisions of EU law and secondly - by introducing the principle of budgetary balance into the constitution.

In the light of article 109 (2) of the Basic Law, the Federation and the Länder shall jointly discharge the obligations of the Federal Republic of Germany resulting from legal acts of the European Community for the maintenance of budgetary discipline pursuant to Article 104 of the Treaty Establishing the European Community and shall, within this framework, give due regard to the requirements of overall economic equilibrium.

Moreover, the budgets of the Federation and the Länder shall be balanced without revenue from credits (article 109 (3)) This principle shall be satisfied when revenue obtained by the borrowing of funds does not exceed 0.35 per cent in relation to the nominal gross domestic product. Temporary deviation from this principle are allowed in the case of natural catastrophes or unusual emergency situations beyond governmental control and substantially harmful to the state's financial capacity and should be approved by an absolute majority of the members of the lower house of parliament.

\subsection{Spain}

German solutions were certainly a source of inspiration for the Spanish. Before financial crisis of 2008, Constitution of Spain did not contain strict limitation of fiscal policy, however its was modified in 2011. The revision of Spanish constitution was enormously fast. The whole procedure took 32 days, which excluded the possibility of real debate, on the other hand in 2011 Spain was in an extremely difficult financial situation, with markets reluctant to buy Spanish debt, therefore it was necessary to send a signal to those markets [Robledo 2016: 222]. 
The amended version of Article 135 (1) of Constitution of Spain requires that all public administrations will conform to the principle of budgetary stability. Constitution of Spain also provides the State and the self-governing communities may not incur structural deficit that exceeds the limits established by the EU for its Member States. Moreover, in the light of article 135 (3) the volume of public debt of all the public administrations in relation to the State gross domestic product may not exceed the benchmark laid down by the Treaty on the Functioning of the European Union.

The Spanish Constitution stipulates that organic law shall determine the maximum structural deficit for State and for the Autonomous Communities. On the other hand local authorities shall present a balanced budget (Article 135(2)). Under the current provisions passing, amendment or repeal of the organic laws shall require an absolute majority of the members of Congress (Article 81 (2)). In this aspect Spanish constitutional rule seems to be more flexible than German provisions - it only requires an organic law modification to set the maximum level of deficit.

The Spanish Constitution also provides an escape clause, according to which the limits of the structural deficit may be exceeded only in cases of natural disasters, economic recession or extraordinary emergency situations that are beyond the control of the State and significantly impair either the financial situation or the economic or social sustainability of the State (Article 135(4)).

\subsection{Italy}

Financial crisis of 2008 has also led the constitutional amendment in Italy. In the light of new provisions the State shall balance revenue and expenditure in its budget, taking into account the adverse and favourable phases of the economic cycle (Article 81(1) of Constitution of Italy. The above mentioned rule can be derogated in order to counteract the effect of economic cycle and by a law adopted by an absolute-majority in exceptional circumstances (Article 81(2)).

The content of the budget law, the fundamental rules and the criteria adopted to ensure balance between revenue and expenditure and the sustainability of general government debt shall be established by legislation approved by an absolute majority of the Members of each House in compliance with the principles established with a constitutional law (article 81(6)). Such legal act was adopted at the end of 2012 (Law 243/2012). It should be taken into consideration that the Italian legal order does not include, in its system of 
sources, formal organic laws, but the Law $243 / 2012$ is in some ways comparable to that model, in particular:

1) this law may be "repealed, modified or waived only expressly" by a subsequent law passed by the same special majority and amending of this act must necessarily be approved by two Chambers;

2) this special law cannot rule, in such a reinforced way, on matters already covered by ordinary legislation and outside its predicted area of competence;

3) the Government cannot intervene on such matters by decree-law or by delegated legislation [Pierdominici 2014: 11].

The Italian amendment introduced also public debt restrictions by a general reference to the provisions of EU. In the light of article 97 (1) general government entities shall ensure balanced budgets and the sustainability of public debt in accordance with European Union law. Moreover municipalities, provinces, metropolitan cities and regions shall have revenue and expenditure autonomy, subject to the obligation to balance their budgets, and shall contribute to ensuring compliance with the economic and financial constraints imposed under European Union law (Article 119(1)).

\subsection{Slovakia}

At the end of 2011, the Slovak Parliament adopted significant constitutional amendment, which aims to achieve long term sustainability of state's economy, enhance transparency and efficiency of public spending and to encourage long-term competitiveness of Slovakia, while taking into account the requirements of economic and social justice and solidarity between present and future generations [Babčák 2013: 64].

The Fiscal Responsibility Constitutional Act (hereinafter as: Constitutional Act) is a separate constitutional law. It should be explained, that within the Slovak legal order there are two forms of parliamentary legislation in Slovakia - constitutional acts and ordinary statutes. All constitutional acts are in theory equal, however the Constitution is the central constitutional act. That means the position of Fiscal Responsibility Constitutional Act within the Slovak legal order would be the same if it were enacted as an amendment to the Constitution [Dumbrosky 2014: 11]. Slovak solutions are more comprehensive among others. It covers the following areas:

1) Establishment of the Fiscal Responsibility Council,

2) Fiscal Responsibility Rules 
3) Rules of transparency in public finance.

Constitutional Law established the Fiscal Responsibility Council as independent body set up to monitor and evaluate the fiscal performance of the Slovak Republic and evaluate compliance with the fiscal responsibility rules (article $3(1)$ ). The Council consists of three members, the chairman and two other members. They are to be elected by Parliament for seven years term.

Fiscal responsibility rules contained in the Constitutional Act are focus on the debt levels. The upper limit of the general government debt shall be $50 \%$ of gross domestic product (article 5(1)). The Debt amount means the amount of the Debt of the Slovak Republic published from time to time by the European Commission (Eurostat) expressed as a percentage of gross domestic product (article 5 (2)). Constitutional law provides the debtreducing procedure. If the debt amount reaches (after 2027):

1) From $40 \%$ to $43 \%$ share of GDP, the Ministry of Finance shall all submit to the National Council a written justification of the debt amount, including the proposed measures for debt reduction.

2) From $43 \%$ to $45 \%$ share of GDP, the Government has an obligation to submit draft measures on debt reduction to the Parliament. At the same time salaries of members of the Government shall be reduced to the level of preceding year.

3) From $45 \%$ to $47 \%$ share of GDP, in addition to implementing the above mentioned procedure,

a) the Ministry of Finance shall block, as of the first calendar month following the month in which the Debt amount was published, the state-budget expenditures in the amount of $3 \%$ of the total state-budget expenditures as approved in the State Budget Act for the respective fiscal year less the expenditures on government debt service, the European Union funds, statebudget funds earmarked for the financing of joint programmes between the Slovak Republic and the European Union, transfers to the Social Insurance Agency and expenditures designed to remedy damages caused by natural disasters;

b) no funds shall be released from the reserve of the Prime Minister and the reserve of the Government;

c) the Government may not submit to the National Council any general government budget proposal entailing a nominal year-on-year increase in consolidated general government expenditures compared to the general government budget for the previous fiscal year, except for the expenditures 
on government debt service, state-budget funds earmarked for the financing of joint programmes between the Slovak Republic and the European Union, transfers to the European Union, and expenditures designed to remedy damages caused by natural disasters; if the Government had already submitted such a general government budget proposal, it shall withdraw it from the National Council and, within 30 days, submit a new general government budget proposal complying with these conditions, and

d) municipalities and self-governing regions shall be obliged to approve their budgets for the following fiscal year with expenditures not exceeding their previous fiscal year's level, except for the expenditures designed to remedy damages caused by natural disasters and the funds earmarked to finance joint programmes between the Slovak Republic and the European Union.

4) From $45 \%$ to $47 \%$ share, in addition to the procedures laid down above in

a) the Government may not submit to the National Council a general government budget proposal with budgeted deficit; if the Government had already submitted such a general government budget proposal, it shall withdraw it from the National Council and, within 30 days, submit a new general government budget proposal complying with these conditions.

b) municipalities and self-governing regions shall be obliged to approve their budgets for the following fiscal year as balanced budgets or surplus budgets

5) If the debt amount exceeds $50 \%$ of gross domestic product, in addition to the procedures applied under paragraphs the Government shall ask the National Council for a vote of confidence.

During financial years 2012 to 2017, the maximal limit of government debt was $60 \%$ of GDP. Starting from the fiscal year of 2018 and until the end of the fiscal year of 2027, the upper limit of the general government debt and debt ranges in reducing procedure shall be set one percentage point below the upper limit of the general government debt applicable in the previous fiscal year (article 13 of Constitutional Act).

\subsection{Hungary}

The Constitution of Hungary introduces the principle according to which Hungary shall enforce the principle of balanced, transparent and sustainable budget management. In this respect, the Parliament and the Government shall have primary responsibility for the observance of this principle. Moreover the Constitutional Court, the courts, the local 
governments and other state organs are also obliged to respect it in performing their duties (Article $\mathrm{N}$ of Constitution Of Hungary).

However the Constitution of Hungary focuses more on the principle of sustainable debt. In the light of its article 36 (4), the Parliament may not adopt state budget act which would result in state debt exceeding half of GDP. As long as state debt exceeds half of the GDP, the Parliament may only adopt a State Budget Act which contains state debt reduction in proportion to the Gross Domestic Product (article 36(5)). Moreover, no debt or financial obligation may be assumed which allows the share of state debt related to the Gross Domestic Product to exceed its level in the previous year (Article 37(3)).

Any deviation from above mentioned principle shall only be possible during a special legal order, to the extent required for mitigating the consequences of the causes, and if there is a significant and enduring national economic recession, to the extent required for redressing the balance of the national economy (article 36 (6)). The Constitution of Hungary also indicates that ordinary legislation lays down the method for calculating state debt and the GDP as well as the rules relating to the implementation of budgetary rules (Article 37(5)).

In order to enforce debt limit, the Constitution od Hungary has established the Budget Council, consisting of the President of the Budget Council, the Governor of the National Bank of Hungary and the President of the State Audit Office. The Budget Council shall be an organ supporting Parliament's legislative however, its position is extraordinarily strong [Antos 2014: 215]. According to the article 43 Hungarian Constitution, the adoption of the State Budget Act shall be subject to the prior consent of the Budget Council in order to meet the requirements set out in constitutional fiscal rule. Its decision may not be reviewed or annulled, so the Budget Council have a real veto right, which is an exceptional restriction of parliament's budgetary power. [Szente 2016: 362]. Consequently the Budget Council decision could lead to the fall of the government if the budget act for a given year is not accepted by 31 March of that year, the President of the Republic may dissolve Parliament and order new elections (article 3(3)).

It should be emphasized, that Hungarian constitution introduce limitation of judicial control over public finance. The Constitutional Court may review the Acts on the central budget, the implementation of the central budget, central taxes, duties and contributions, customs duties and the central conditions for local taxes in terms of conformity with the Constitution exclusively in connection with the rights to life and human dignity, the protection of personal data, freedom of thought, conscience and religion, or the rights 
related to citizenship. The Constitutional Court shall have the unrestricted right to annul the related Acts for non-compliance with the Fundamental Law's procedural requirements for the drafting and publication of such legislation (Article 37(4)). The elimination of constitutional review from public finance issues, raises the assumption that this kind of constitutional regulation appears to give an unlimited entitlement to the executive power, allowing even an unconstitutional economic or financial policy [Szente 2016: 359].

\subsection{Slovenia}

The principle of a balanced budget has also been introduced into the Constitution of Slovenia. According to its article 148 revenues and expenditures of the budgets of the state should be balanced in the medium-term without borrowing, or revenues must exceed expenditures. Temporary deviation from this principle is only allowed when exceptional circumstances affect the state. The manner and the time frame of the implementation of the principle referred to in the preceding paragraph, the criteria for determining exceptional circumstances, and the course of action when they arise, shall be determined by a law adopted by the National Assembly by a two-thirds majority vote of all deputies.

The Slovenian rule on the constitutional grounds consists only the obligation to maintain a balance between state revenues and expenditure. It does not include the limit of the budget deficit (stipulated as percentage to GDP), however this matter has been regulated in special act (Fiscal Rule Act). According to Article 3 (1) of Fiscal Rule Act, revenues and expenditures of the budgets of the state shall be balanced in the medium term without borrowing, if the structural balance of the general government sector in an individual year is not lower than the minimum value as defined in the ratified international treaty on stability, coordination and governance in economic and monetary union, and in the medium term is at least in balance or in surplus.

A deviation from the medium-term balance shall only be permitted provided that it does not endanger fiscal sustainability in the medium term, and only in periods of severe economic downturn or the case of an unusual event outside the control of the party concerned which has a major impact on the financial situation of the general government sector, as defined by the Stability and Growth Pact. The Government shall determine whether exceptional circumstances exist or have ceased to exist, after obtaining the assessment of the Fiscal Council. The Fiscal Council shall provide the assessment as to whether circumstances exist or have ceased to exist in no later than 15 days, if the assessment is requested by the Government (Article 12 of Fiscal Rules Act). 


\section{The method of consitutionalisation}

While the objectives and reasons of constitutionalisation fiscal restrictions remain largely common to all countries, the methods of constitutionalisation are different. Distinctions are focused on fiscal rules criterion, reference to EU law and structural approach.

\subsection{Fiscal rules criterion}

A substantial difference can be observed in the selection of the central criterion of fiscal rule. While in Germany, Spain, Slovenia and Italy it primarily the budget deficit, in Poland, Hungary and Slovakia is primarily debt amount expressed relative to GDP.

Debt rules seem to be more flexible. They are focus more on long-term stability rather than current fiscal policy and budget deficit. Using debt as the central criterion might seem like a sound idea at first sight as it goes to the core of the problem: the state budget may be in deficit from time to time, especially during economic downturns, but the overall debt should be kept within some reasonable limits [Antos 2014: 212]. To avoid debt level breach, some supportive mechanisms have been introduced. Specially in Slovakia is then required to adopt special debt debt-reducing procedure stipulated in Constitutional Act. In Poland similar solutions (prudential and remedial procedure) were enacted in Poland in Public Finance Act (Articles 86-88).

Nevertheless there are some problems concerning to debt rules. It should be taken into consideration that it is difficult to determine one universal appropriate level of indebtedness. However in the light of research conducted by C. Reinhart and K. Rogoff, there is no obvious link between debt and growth until public debt reaches a threshold of 90 percent. The observations with debt to GDP over 90 percent have median growth roughly 1 percent lower than the lower debt burden groups and mean levels of growth almost 4 percent lower [Reinhart, Rogoff 2010: 575-577].

\subsection{Reference to EU law}

It is noteworthy that some Constitutions establish direct reference to the EU criterion. In the light of the Constitution of Germany, the Federation and the Länder shall jointly discharge the obligations of the Federal Republic of Germany resulting from legal acts of the European Community for the maintenance of budgetary discipline pursuant to Article 104 of the Treaty Establishing the European Community and shall, within this framework, 
give due regard to the requirements of overall economic equilibrium. The Constitution of Spain provides that volume of public debt of all the public administrations in relation to the State' gross domestic product may not exceed the benchmark laid down by the Treaty on the Functioning of the European Union (Article 135 (3)). Reference to EU law is also made in Constitution of Italy indicating that general government entities, in accordance with European Union law, shall ensure balanced budgets and the sustainability of public debt. (Article 97(1)). The Slovenian legislator, on the other hand, do not refer to the EU regulations in the Constitution, but in the provisions detailing the constitutional fiscal rule.

In Slovakia, the Constitutional Act does not contain direct reference to EU criteria, however there is reference to EU definition of public debt. According to article 5 (2) the debt amount means the amount of the debt of the Slovak Republic published from time to time by the European Commission (Eurostat) expressed as a percentage of gross domestic product.

Against this background, it is evident that Polish and Hungarian solutions seem to be less related to EU solutions. The Polish and Hungarian provisions does not refer to EU standards by indicating a specific provision or a more general reference. However, the debt level stipulated in Polish Constitution (article 216 (5)) refers to Maastricht criterion.

\subsection{Structural approach and escape clauses}

It should be take into consideration that new wave of constitutional fiscal policy takes structural approach and include escape clauses, which make these rules more flexible. In new fiscal policy rules stipulated in Constitutions there is a target for the structural deficit (the actual deficit corrected for the effects of the economic cycle as well as the one-off and temporary fiscal measures). Constitutional fiscal rules also include escape clauses in the case of an unusual event outside the control of the state which has a major impact on the fiscal situation (economic downturns, natural disasters, wars etc.).

Germany's 2009 amendment requires, unless there is disaster or serve economic crisis, the federal government may run a structural deficit of no more than $0,35 \%$ of GDP. Moreover, in cases of natural catastrophes or unusual emergency situations beyond governmental control and substantially harmful to the state's financial capacity, these credit limits may be exceeded on the basis of a decision taken by a majority of the Members of the Bundestag. In Spain The Constitution also provides an escape clause, according to which the limits of the structural deficit may be exceeded in cases of natural disasters, economic recession or 
extraordinary emergency situations that are beyond the control of the State and significantly impair either the financial situation or the economic or social sustainability of the State (Article 135(4)).

Italy's rule also takes a structural approach; it states that the State shall balance revenue and expenditure in its budget, taking account of the adverse and favourable phases of the economic cycle.

In Hungary any derogation from debt rule shall only be allowed during a special legal order and to the extent necessary to mitigate the consequences of the circumstances triggering the special legal order, or, in case of an enduring and significant national economic recession, to the extent necessary to restore the balance of the national economy.

Slovenia's provisions stipulated that revenues and expenditures of the budgets of the state should be balanced in the medium-term without borrowing, or revenues must exceed expenditures. Temporary deviation from this principle is only allowed when exceptional circumstances affect the state.

Polish debt rule does not provide an escape clause. Exceeding the debt level of 3/5 of GDP is a violation of the article 216 (5) of Constitution of Poland. The incurring of financial obligations by the relevant bodies, as a result of which the constitutional limit would be exceeded, results in committing a constitutional tort. Nevertheless, in case of exceeding the debt limit, it seems crucial to take into account the context in which the constitutional norm was violated, and the need to do so in order to protect (realise) other constitutional value.

\section{Effectiveness of constitutional fiscal policy rules}

According to the economic research, there is no one obvious evidence, that the constitutional fiscal policy rules are more effective than similar rules stipulated in other legal acts. T. Ginsburg points out that there is no particular difference between fiscal rules at the constitutional level or an international treaty. As he notes, the lowest level of deficit is reached by countries whose fiscal rules have been regulated in political acts (coalition agreements, political commitments), however, limitations of fiscal policy in political acts occur in highly developed countries. The above observations do not lead the author to conclusion that constitutional fiscal rules are not useful. In his opinion, these tools are an important point of reference for the conducted fiscal policy, being a kind of "speed limit" [Ginsburg 2019: 69-70]. 
J. Amick, T. Chapman, and Z. Elkins indicate that it is not necessary to introduce fiscal rules at the constitutional level, however, the fiscal policy conducted on the basis of constitutional norms may be more consistent. At the same time, according to these authors, countries with constitutional rules of balanced budget are less prone to create budget deficits, more often achieve budget surplus and the fiscal policy pursued on the basis of constitutional norms is more consistent [ Amick, Chapman, Elkins 2019, 30].

Among the countries examined, the particularly noteworthy situation is in Germany, where a significant decline in debt in the short term and the budget surplus has been achieved. The literature contains different opinions, according to which the good results of the German fiscal policy in recent years are not due to the 'debt brake', but to the favourable macroeconomic situation. [K. Rietzler, A. Truger 2018 2-3] In comparison with other rules, German solutions seem to be more detailed, and additionally they are characterised by an above-average level of rigour. The solutions adopted in Germany were not adopted ad hoc in response to the outbreak of the financial crisis - debate on the reform started already in 2006.

Table 1. The general government debt in selected EU Countries

\begin{tabular}{|l|c|c|c|c|c|c|c|c|c|c|c|c|}
\cline { 2 - 12 } \multicolumn{1}{c|}{} & 2008 & 2009 & $\mathbf{2 0 1 0}$ & $\mathbf{2 0 1 1}$ & $\mathbf{2 0 1 2}$ & $\mathbf{2 0 1 3}$ & $\mathbf{2 0 1 4}$ & $\mathbf{2 0 1 5}$ & $\mathbf{2 0 1 6}$ & $\mathbf{2 0 1 7}$ & $\mathbf{2 0 1 8}$ & $\mathbf{2 0 1 9}$ \\
\hline Poland & 46,7 & 49,8 & 53,5 & 54,5 & 54,1 & 56,0 & 50,8 & 51,3 & 54,3 & 50,6 & 48,8 & 46,0 \\
\hline Germany & 65,5 & $\underline{73,0}$ & 82,4 & 79,8 & 81,1 & 78,7 & 75,7 & 72,1 & 69,2 & 65,3 & 61,9 & 59,8 \\
\hline Spain & 39,7 & 53,3 & 60,5 & $\underline{69,9}$ & 86,3 & 95,8 & 100,7 & 99,3 & 99,2 & 98,6 & 97,6 & 95,5 \\
\hline Italy & 106,2 & 116,6 & 119,2 & 119,7 & $\underline{126,5}$ & 132,5 & 135,4 & 135,3 & 134,8 & 134,1 & 134,8 & 134,8 \\
\hline Hungary & 71,8 & 78,2 & 80,6 & $\underline{80,8}$ & 78,6 & 77,4 & 76,8 & 76,2 & 75,5 & 72,9 & 70,2 & 66,3 \\
\hline Stovakia & 28,6 & 36,4 & 41,0 & $\underline{43,5}$ & 51,8 & 54,7 & 53,5 & 51,9 & 52,0 & 51,3 & 49,4 & 48,0 \\
\hline Slovenia & 21,8 & 34,5 & 38,3 & 46,5 & 53,6 & $\underline{70,0}$ & 80,3 & 82,6 & 78,7 & 74,1 & 70,4 & 66,1 \\
\hline \hline $\begin{array}{l}\text { UE } \\
\text { average }\end{array}$ & 61.3 & 74.0 & 79.6 & 82.0 & 84.4 & 86.3 & 87.0 & 84.9 & 83.8 & 82.1 & 80.4 & 79.3 \\
\hline
\end{tabular}

Source: Author's own elaboration based on Eurostat data.

The presented data shows that during financial crisis of 2008 , there was no violation of the public debt ceiling stipulated in article 216 (5) of the Constitution of Poland. In 2008 in 3 states (Spain, Slovenia, Slovakia) the debt level was higher than in Poland. Then, as a result of the financial crisis, above mentioned value increased significantly, exceeding $60 \%$ in two cases (Spain, Slovenia). In Slovakia in critical moment (2013), this level approached 55\% of 
GDP (from 28.6\% in 2008). In Poland the debt increased from nearly 47\% of GDP in 2008 to $56 \%$ of GDP in 2013.

This observation may give rise to the conclusion that the reduction of fiscal policy under article 216 (5) of the Polish Constitution provides effective protection against the occurrence of excessive debt. Moreover, it is noticeable that in 2019 in 5 countries (Poland, Germany, Hungary, Slovakia, Slovenia) the debt level remained below the average of EU countries, which mostly proves the effectiveness of examined fiscal policy rules. In 2 cases (Spain, Italy) these values were much higher.

The Polish legislator decided to set the debt ceiling at $60 \%$ of GDP. The other constitutional debt rules set the ceiling 10 p.p. lower. According to the above data, the planned level in Slovakia was already achieved in 2018, which also confirms the effectiveness of constitutional fiscal policy rule. The situation is slightly different in Hungary, where in 2019, the level of public was more than $16 \mathrm{pp}$. higher than the constitutional limit, however it remained below the average of EU countries. Among the countries whose constitutions contain balanced budget rule, Germany and Slovenia has made the most progress. In contrast in Italy and Spain the situation is different.

It seems that that constitutional fiscal policy rules can be useful tool, however in practice it is extremely difficult to draw unambiguous conclusions due to the small number of countries introducing such solutions [Blume, Voight 2013: 244]. The compliance with such instruments is affected by many factors i.e rate of economic growth, political culture, the level of economic education of the society. Only in a longer perspective will it be possible to evaluate the adopted instruments - one of the most important will be an economic crisis caused by a global pandemic.

It should be also taken into consideration, that a significant problem remains the method of debt calculation.

The presented data show that in recent years the level of national public debt protected by the Polish Constitution has been lower than the debt of the general government sector. Statutory definition of national public debt seems to be one of the most important problem. There is a temptation to "reduce" debt level artificially by appropriate definitional changes. This problem is particular important in recent years as a result of measures introduced as response to the economic crisis caused by a global pandemic. In third quarter of 2020 , the general government debt reached $56,7 \%$ of GDP [Eurostat]. 
Table 2. Public debt in Poland

\begin{tabular}{|c|c|c|}
\hline Fiscal year & National public debt & General government debt \\
\hline $\mathbf{1 9 9 7}$ & 50,7 & 41,4 \\
\hline $\mathbf{1 9 9 8}$ & 49,1 & 39,5 \\
\hline $\mathbf{1 9 9 9}$ & 40 & 39,6 \\
\hline $\mathbf{2 0 0 0}$ & 37,7 & 35,7 \\
\hline $\mathbf{2 0 0 1}$ & 38,7 & 37,3 \\
\hline $\mathbf{2 0 0 2}$ & 43,5 & 41,8 \\
\hline $\mathbf{2 0 0 3}$ & 48,3 & 46,6 \\
\hline $\mathbf{2 0 0 4}$ & 46,2 & 45,1 \\
\hline $\mathbf{2 0 0 5}$ & 47,1 & 46,6 \\
\hline $\mathbf{2 0 0 6}$ & 47,3 & 47,3 \\
\hline $\mathbf{2 0 0 7}$ & 44,4 & 44,5 \\
\hline $\mathbf{2 0 0 8}$ & 46,5 & 46,7 \\
\hline $\mathbf{2 0 0 9}$ & 48,8 & 49,8 \\
\hline $\mathbf{2 0 1 0}$ & 51,7 & 53,5 \\
\hline $\mathbf{2 0 1 1}$ & 52,0 & 54,5 \\
\hline $\mathbf{2 0 1 2}$ & 51,6 & 54,1 \\
\hline $\mathbf{2 0 1 3}$ & 53,2 & 56,0 \\
\hline $\mathbf{2 0 1 4}$ & 48,1 & 50,8 \\
\hline $\mathbf{2 0 1 5}$ & 48,7 & 51,3 \\
\hline $\mathbf{2 0 1 6}$ & 51,9 & 54,3 \\
\hline $\mathbf{2 0 1 7}$ & 48,3 & 50,6 \\
\hline $\mathbf{2 0 1 8}$ & 46,4 & 48,8 \\
\hline $\mathbf{2 0 1 9}$ & 43,6 & 46,0 \\
\hline
\end{tabular}

Source: Author's own elaboration based on Eurostat and Ministry of Finance data.

\section{Conclusions}

The example of Poland, where the numerical rule was introduced in 1997, shows that in a longer term such tools provide optimal protection of public finance. Since the adoption of the Constitution of the Republic of Poland public debt has never exceed the level of $60 \%$ of GDP. Polish solutions proved to be effective during the financial crisis of 2008. Moreover, it is noticeable that in 2019 in 5 countries (Poland, Germany, Hungary, Slovakia, Slovenia) the debt level remained below the average of EU countries, which mostly proves the effectiveness of examined fiscal policy rules.

The presented analyses indicate that constitutional fiscal rules should not be remove. This kind of instruments may have a positive impact on the state of public finances, however in practice it is extremely difficult to draw unambiguous conclusions due to the small number of countries introducing such solutions. The Polish example cannot be a basis for giving an unambiguously positive answer in this aspect. Other fiscal rules, on the other hand, have been regulated relatively recently, which does not give grounds to draw unambiguous 
conclusions. Only in a longer perspective will it be possible to evaluate the adopted instruments - the first major challenge for the discussed rules will be the economic crisis caused by the global pandemic.

Moreover, the significant problem from the point of view of the effectiveness of Polish debt rule is the method of debt calculation. The presented data show that in recent years the level of national public debt protected by the Polish Constitution has been lower than the debt of the general government sector. Additionally, it should be emphasized that the current categorical formulation of the constitutional debt rule remains problematic. It is worth considering the proposal to introduce into Article 216 (5) of the Constitution of the Republic of Poland escape clauses. Therefore, discussion should not be focus on removal of constitutional fiscal policy rules but on the construction of this instruments. 


\section{References}

Amick J., Chapman T., Elikins Z., On Constitutionalizing a Balanced Budget

Available at:

http://comparativeconstitutionsproject.org/wp-content/uploads/amick-chapman-elkins2019.pdf?6c8912, accessed: 20 ${ }^{\text {th }}$ January 2021.

Antos M., Fisacal Stability Rules in Central Europe Constitutions (in:) Adams M., Fabbrini F., Larouche P. (eds.): The Constitutionalization of European Budgetary Constraints, Oxford: Hart Publishing, 2014.

Babčák V., The Constitutional Fiscal Responsibility in the Slovak Budgetary Law (in:) Ruśkowski E., Stankiewicz J., Tyniewicki M., Zawadzka-Pąk U.K. (eds.), Annual and Long Term Public Financesin Central and Eastern European Countries, Białystok: Temida 2, 2013.

Blume L., Voight S. , The economic effects of constitutional budget institutions, European Journal of Political Economy no. 29, 2013.

Dębowska - Romanowska T.: Prawo finansowe część konstytucyjna wraz z częścią ogólną [Financial law constitutional part with the general part], Warsaw: C.H. Beck, 2010.

Dumbrosky T., Constitutional change through euro crisis law: Slovakia Available at: https://eurocrisislaw.eui.eu/country-reports/ accessed: 20 ${ }^{\text {th }}$ January 2021.

Gerapetritis G., New Economic Constitutionalism in Europe, London: Hart Publishing, 2019.

Ginsburg T, Balanced Budget Provisions in Constitutions (in:) Ginsburg T., Rosen M.D., Vanberg G. (eds.): Constitutions in times of financial crisis, Cambridge: Cambridge University Press, 2019.

Kopits, G.; Symansky, S. Fiscal Policy Rules. Washington: International Monetary Fund, 1998.

Pierdominici L., Constitutional Change Through Euro Crisis Law: Italy

Available at: https://eurocrisislaw.eui.eu/country-reports/ accessed: 20th January 2021

Reinhart C.M., Rogoff K.S., Growth in a Time of Debt, American Economic Review, no. 2, 2010.

Rietzler K., Truger A., Is the debt brake behind Germany's successful fiscal consolidation?, IPE Working Papers, no. 105, 2018.

Robledo A.R, The Spanish Constitution in the Turmoil of the Global Financial Crisis (in:) Contiades X. (eds.): Constitutions in the Global Financial Crisis, A Comparative Analysis, New York: Routledge 2016.

Sokolewicz W., Komentarz do art. 216- 220 [Commentary to Articles 216- 220 ] (in:) Garlicki L. (ed.): Konstytucja Rzeczypospolitej Polskiej. Komentarz [Commentary on the Constitution of Republic on Poland], Warsaw: Wydawnictwo Sejmowe [Seym Publishing Press], 2005.

Szente Z., Breaking and Making Constitutional Rules: The Constitutional Effects of the Financial Crisis in Hungary (in:) Contiades X. (eds.): Constitutions in the Global Financial Crisis, A Comparative Analysis, New York: Routledge, 2016.

\section{Legal Acts}

Treaty on Stability Coordination and Governance in the Economic and Monetary Union (Polish Journal of Laws 2013, item 1258).

The Constitution of the Republic of Poland of 2nd (Journal of Laws 1997, No 78, item 483, as amended).

Act of 27 August, 2009 on Public Finance (consolidated text Journal of Laws 2017, item 2077, as amended) [Poland].

Constitution of Germany

Available at: https://www.constituteproject.org/, accessed: 20 th January 2021.

Constitution of Hungary

Available at: https://www.constituteproject.org/, accessed: $22^{\text {nd }}$ January, 2021.

Constitution od Italy, Available at: https://www.constituteproject.org/, accessed: 22th January 2021.

The Fiscal Responsibility Constitutional Act [Slovakia]

Available at: https://www.rozpoctovarada.sk/images//constitutional_act_493_2011.pdf., accessed: $20^{\text {th }}$ January, 2021.

Constitution of Slovenia

Available at: https://www.constituteproject.org/, accessed: 20th January, 2021.

The Fiscal Rule Act [Slovenia] 
Available at: http://www.fs-rs.si/wp-content/uploads/2018/02/ZFisP_EN.pdf, accessed: $20^{\text {th }}$ January, 2021.

Constitution of Spain[Spain]

Available at: https://www.constituteproject.org/, accessed: 21 $1^{\text {st }}$ January 2021.

\section{Internet Resources}

Eurostat Data Browser

Available at:

https://ec.europa.eu/eurostat/databrowser/view/teina230/default/table?lang=en, accessed: 31 ${ }^{\text {st }}$ January, 2021. 